\title{
Pengaruh Posisi Penyemprotan Bahan Bakar Gas Lpg Pada Intake Manifold Terhadap Konsumsi Bahan Bakar Pada Mesin Bensin Empat Langkah Satu Silinder (Honda Supra X)
}

\author{
I Made Nuarsa*, I Made Mara**, Riskon \\ *,** Dosen Fakultas Teknik Universitas Mataram \\ Jalan. Majapahit No. 62 Mataram
}

\begin{abstract}
One of major sources of air pollution is the result of combustion exhaust gases of automotive engines. As it is known that the process of fuel combustion from motor fuel produces exhaust gases which theoretically contain elements of $\mathrm{CO}, \mathrm{NO}_{x}, \mathrm{HC}, \mathrm{CO}_{2}, \mathrm{H}_{2} \mathrm{O}$ and $\mathrm{N}_{2}$, where many of which are polluting the surrounding environment in the form of air pollution.

The use of LPG fuel for gasoline engine can be done by adding a piece of equipment called a conversion kit. In this study the fuel in the LPG gas injected in the intake manifold with some variation of spin injection with 3000 rpm, $4500 \mathrm{rpm}$ and $6000 \mathrm{rpm}$ for each transmision rate (Neutral s / $d$ Gear 4).

The result showed that the injection of fuel gas LPG in the rear position (P3) in getting a decrease in fuel Consumtion (FC) is optimal compared to other injection position (P1, P2). In addition the maximum fuel. Consumtion obtained at transmission rate at each round of variation mesin. Lowes CO emission levels found in LPG fuel injection in the rear position (P3) on the engine rev $3000 \mathrm{rpm}$ kadar CO2 in round 3000 engine rpm optimum obtained from the use of LPG gas fuel injection in the rear position (P3) fornearly all transmision levels. Lowest HC emission values obtained on the location of the feul gas injection LPG rear position (P3) at 3000 rpm rotation at the $4^{\text {th }}$ gear.
\end{abstract}

Key words : emission, conversion kit, fuel consumption, intake manifold.

\section{PENDAHULUAN}

Perkembangan otomotif sebagai alat transportasi, baik di darat maupun di laut, sangat memudahkan manusia dalam melaksanakan suatu pekerjaan. Selain mempercepat dan mempermudah aktivitas, di sisi lain penggunaan kendaraan bermotor juga menimbulkan dampak yang sangat buruk terhadap lingkungan, terutama gas buang dari hasil pembakaran bahan bakar yang tidak terurai atau terbakar dengan sempurna (Anonim 1, 2002).

Kendaraan bermotor yang menggunakan bahan bakar minyak (BBM) mengandung timah hitam (Leaded gasoline) berperan sebagai penyumbang polusi cukup besar terhadap kualitas udara dan kesehatan. Kondisi tersebut diperparah oleh terjadinya krisis ekonomi yang melanda negara, dimana kondisi kendaraan bermotor dan angkutan sangat buruk akibat mahalnya suku cadang dan perawatan yang kurang baik sehingga proses pembakaran yang terjadi kurang sempurna (Abubakar, 2003).

Fenomena ini mendorong manusia untuk berusaha mencari bahan bakar alternatif sebagai pengganti bahan bakar minyak untuk mengoperasikan mesin. Salah satu jenis bahan bakar alternatif yang memungkinkan untuk menggantikan bahan bakar minyak terutama yang akan digunakan untuk kendaraan bermotor adalah bahan bakar gas.

Bahan bakar gas juga memiliki beberapa keuntungan antara lain seperti memiliki AO (angka oktan) yang lebih tinggi dibanding bensin (sekitar 120-
130 dibanding bensin yang hanya sekitar 80 untuk premium dan 94 untuk premix), hasil pembakarannya relatif lebih bersih (mengingat rantai karbon bahan bakar gas yang sangat pendek dibandingkan bensin), umur minyak pelumas juga lebih panjang, dan berbagai keuntungan lainnya. (Tirtoatmodjo; et. al, 1999).

Jenis bahan bakar gas yang sering digunakan adalah LPG (Liquifed Petroleum Gas). Senyawa yang terdapat dalam LPG adalah propana $\left(\mathrm{C}_{3} \mathrm{H}_{8}\right)$, Propilen $\left(\mathrm{C}_{3} \mathrm{H}_{6}\right)$, iso-butan $\left(\mathrm{C}_{4} \mathrm{H}_{10}\right)$ dan Butilen $\left(\mathrm{C}_{4} \mathrm{H}_{8}\right)$. LPG merupakan campuran dari hidrokarbon tersebut yang berbentuk gas pada tekanan atmosfir, namun dapat diembunkan menjadi bentuk cair pada suhu normal, dengan tekanan yang cukup besar. Walaupun digunakan sebagai gas, namun untuk kenyamanan dan kemudahannya, disimpan dan ditransport dalam bentuk cair dengan tekanan tertentu. LPG cair, jika menguap membentuk gas dengan volume sekitar 250 kali (Anonim 2, 2006).

\section{LANDASAN TEORI}

Jumlah persediaan minyak bumi yang mulai menipis mengakibatkan kelangkaan minyak bumi dan memberi dampak yang besar pada tiap-tiap Negara terutama Negara-negara berkembang seperti Indonesia. Kelangkaan minyak bumi secara langsung akan memiliki dampak besar pada sektor perekonomian dan transportasi. Menipisnya persediaan minyak bumi menjadi penyebab utama kelangkaan bahan bakar untuk transportasi dan industri. Harga 
minyak mentah pada tahun 2000 yang berkisar \$5 $\$ 10$ per barrel, kini pada tahun 2008 telah melebihi $\$ 50$ per barrel. (Peak oil and the extinction of humanity, October 10,2006).

Indonesia memilki sumber gas alam yang berlimpah dan saat ini merupakan eksportir gas alam terbesar di dunia. Saat ini bahan bakar gas telah terbukti sebagai pilihan yang lebih baik di bidang transportasi. Data menunjukkan bahwa bahan bakar gas yang mulai dicoba oleh pemerintah melalui pertamina pada tahun 1987 memiliki beberapa keuntungan diantaranya lebih murah dari bahan bakar minyak, lebih ringan dari udara, usia mesin lebih lama, perawatan lebih murah dan tidak mencemari lingkungan. Tapi masalahnya adalah perkembangan bahan bakar gas di masyarakat sangatlah lambat. Hal ini disebabkan antara lain karena harga bahan bakar gas tidak kompetitif dibanding bahan bakar minyak, harga conversion kit yang masih terlalu mahal, dan pemikiran masyarakat yang cenderung untuk selalu menggunakan bahan bakar minyak. Oleh karena itu agar bahan bakar gas menjadi bahan bakar alternatif di bidang transportasi maka diperlukan kebijakan dari pemerintah yang didukung oleh masyarakat (Sitorus, 2002).

Pemakaian bahan bakar gas untuk motor bensin dapat dilakukan dengan menambahkan peralatan yang disebut dengan conversion kit. Namun penggunaannya masih terbatas karena adanya kendala terhadap performa dari motor, yaitu terlalu tingginya putaran pada kondisi idle dan rendahnya akselerasi jika dibandingkan dengan motor yang menggunakan bahan bakar bensin. Salah satu penyebab dari tingginya putaran idle adalah terlalu sedikitnya bahan bakar gas yang masuk ke intake manifold dan specific gravity dari bahan bakar gas $(0.562 \mathrm{~kg} / \mathrm{m} 3)$ lebih rendah dibandingkan dengan bahan bakar bensin, hal ini berakibat kondisi idle dimana katup gas hanya terbuka sedikit, udara yang masuk bersama-sama dengan bahan bakar gas tidak dapat melakukan pembakaran secara sempurna. Salah satu cara untuk memecahkan permasalahannya adalah dengan memberikan suplai bahan bakar gas melalui sistim injeksi yang dikontrol secara elektronik baik pada kondisi idle maupun pada saat akselesari (Kristanto dkk, 2001). Penggantian bahan bakar minyak menjadi bahan bakar gas untuk kendaraan bermotor ternyata mengakibatkan penurunan daya motor yang dihasilkan. Dengan menambahkan peralatan tambahan berupa blower dan injeksi bahan bakar gas, maka tekanan dan kepadatan campuran bahan bakar gas dan udara yang masuk ke dalam ruang bakar bisa lebih tinggi dan daya yang dihasilkan motor bakar lebih meningkat dan bisa menyamai bahkan melebihi daya motor dari motor bakar pada waktu menggunakan bensin (Tirtoatmodjo, dkk,1999).

\subsection{Conversion Kit}

Konversi Kit atau dikenal juga dengan nama Conversion kit merupakan peralatan tambahan pada motor bakar sehingga motor tersebut dapat menggunakan bahan bakar gas. Penggunaan conversion kit didasarkan pada tiga pilihan sebagai berikut :

- Hanya bekerja dengan gas saja

- Dapat bekerja dengan gas saja atau gasoline saja (dual fuel)

- Dapat bekerja dengan dua bahan bakar bersamasama (khusus diesel mixed fuel).

Komponen-komponen perangkat konversi bahan bakar gas tersebut terdiri dari tangki penyimpan bahan bakar gas, regulator (pengatur tinggi rendahnya tekanan), mixer (pencampur udara-bahan bakar). Pada gambar di bawah ini ditunjukkan skema sistim perangkat konversi berbahan bakar ganda (dual fuel) pada kendaraan bermotor.

\subsection{Konsumsi Bahan Bakar (Fuel Consumption)}

Merupakan ukuran pemakaian bahan bakar oleh suatu motor, biasanya diukur dalam satuan volume penggunaan bahan bakar per satuan waktu. Atau juga bisa didefinisikan sebagai jumlah bahan bakar yang dipakai oleh motor untuk menjalankan motor selama watu tertentu, biasanya dalam satuan liter per jam.

Besarnya Fuel Consumption (FC) dapat dihitung dengan persamaan :

$$
\mathrm{FC}=\left(\frac{\text { volumebaha nbakar }}{\text { waktu }}\right) \frac{\text { liter }}{\text { jam }}
$$

\subsection{Bahan Bakar Gas}

Bahan bakar gas adalah gas bumi yang telah dimurnikan dan aman, bersih andal, murah, dipakai sebagai bahan bakar kendaraan bermotor. Komposisi bahan bakar gas sebagian besar terdiri dari gas metana ( $\mathrm{CH} 4$ ) dan etana (C2H6) lebih kurang 90\% dan selebihnya adalah gas propana $(\mathrm{C} 3 \mathrm{H} 8)$, butana (C4H10), pentana (C5H10), nitrogen dan karbon dioksida. Bahan bakar gas lebih ringan daripada udara dengan berat jenis sekitar 0,6036 dan mempunyai nilai oktan 120 (Anonim 4, 2007).

Komposisi utama dari bahan bakar gas adalah unsur metana (CH4) sebesar 95,03\%; etana (C2H6) sebesar 2,23\%; karbondioksida (CO2) sebesar 1,75\%; Nitrogen (N2) $0.68 \%$ dan propana (C3H8) sebesar $0,29 \%$. Dari komposisi ini terlihat bahwa komponen utama dari bahan bakar gas adalah gas methana. Berat jenis bahan bakar gas lebih kecil dari berat jenis udara, sehingga jika terjadi kebocoran baik pada tangki penyimpan maupun saluran bahan bakar akan segera naik ke atas. Bahan bakar gas karena wujudnya berupa gas, tidak perlu diuapkan terlebih dahulu sebagaimana pada bahan bakar minyak (gasoline), sehingga 
permasalahan pada saat start pada suhu rendah dan emisi yang berlebihan karena terlalu kayanya campuran bahan bakar udara pada saat start dapat diperkecil.

Nilai oktan bahan bakar gas lebih tinggi dibandingkan gasoline, yaitu antara 120 sampai 130 . Dengan tingginya nilai oktan tersebut maka pada rasio kompresi yang lebih tinggi tidak akan terjadi knocking pada motor. Keunggulan bahan bakar gas ditinjau dari proses pembakarannya di dalam ruang bakar adalah karena bahan bakar gas memiliki perbandingan atom karbon terhadap atom hidrogen yang rendah, sehingga pembakaran menjadi lebih sempurna. Mengingat bahan bakar gas sudah berada pada fase gas, maka dengan mudah dapat bercampur dengan udara dalam ruang bakar, sehingga oksigen dapat dengan mudah bergabung dengan karbon dan memberikan reaksi pembentukan $\mathrm{CO} 2$ bukan CO. Disamping itu karena jumlah atom karbon molekul bahan bakar gas lebih sedikit dibandingkan bahan bakar minyak, maka $\mathrm{CO}$ yang terbentuk dari proses pembakaran juga lebih sedikit (Philip dkk, 2001).

\section{METODELOGI PENELITIAN}

Dalam penelitian ini ada dua macam variabel yang diukur, yaitu :

Dengan menganalisa variabel terikat diharapkan dapat ditemukan jawaban atau penyelesaian permasalahan. Adapun variabel terikat konsumsi bahan bakar.

2. Variabel bebas

Variabel bebas ialah variabel yang mempengaruhi variabel terikat. Adapun yang merupakan variabel bebas dalam penelitian ini yaitu :

a. Posisi penyemprotan bahan bakar ke dalam intake manifold, yaitu posisi depan, tengah, dan belakang. b. Putaran mesin yang digunakan adalah 3000, 4500, dan 6000 (rpm)

c. Tingkat transmisi kendaraan N, 1, 2, 3, dan 4

d. Data yang didapat dari bahan bakar LPG akan dibandingkan dengan data bahan bakar bensin pada kondisi yang sama.

Untuk menunjang terlaksananya penelitian ini, dibutuhkan beberapa alat berupa :

1. Motor bensin Honda Supra X dengan spesifikasi

Tipe

: Mesin OHC, 4

langkah, pendingin udara

Susunan silinder

kemiringan $80^{\circ}$ dari vertikal

Diameter x langkah

satu silinder,

Volume langkah

: $50 \times 49,5 \mathrm{~mm}$

Perbandingan kompresi

: $97,1 \mathrm{~cm}^{3}$

$: 8,8: 1$

Daya maksimum

: $7,5 \mathrm{DK} / 8.000$

rpm (JIS)

Torsi maksimum

: $0.77 \mathrm{~kg}-\mathrm{m} / 6.000$

rpm

Perbandingan gigi :

Gigi $1 \quad 4,058(69 / 17)$

Gigi 2 2,833 (34/12)

Gigi $3 \quad 1,238(26 / 21)$

Gigi $4 \quad 0.958(23 / 24)$

2. Conversion Kit .

Agar dapat menggunakan bahan bakar gas sebagai bahan bakar untuk kendaraan bermotor dibutuhkan suatu perangkat konversi bahan bakar gas yang disebut dengan conversion kit.

Dalam membuat conversion kit prinsipnya adalah conversion kit tersebut dapat mengatur Flow Rate bahan bakar gas serta tidak mengalami kebocoran.

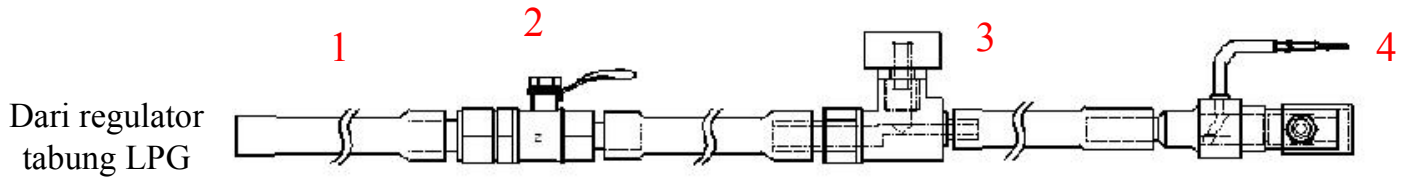

Keterangan : $\quad$ 1. Selang karet

2. katup manual

3. Katup Regulator

4. Katup Throttle.

\section{Pemasangan conversion kit pada mesin}

Pada sistem injeksi, bahan bakar gas langsung dimasukkan kedalam manifold dan bercampur dengan udara di dalam manifold. Dalam hal ini karburator tidak lagi berfungsi sebagai pencampur udara dan bahan bakar melainkan hanya mengatur jumlah udara yang masuk. 


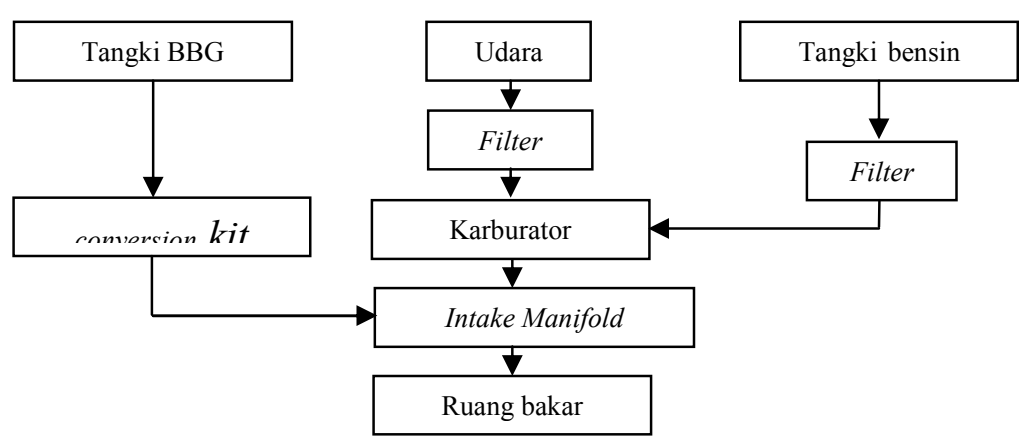

Gambar 2 Conversion kit sistem injeksi

Dalam penelitian ini dilakukan penyemprotan ke dalam intake manifold pada 3 titik yang berbeda sepanjang permukaan intake manifold yaitu pada

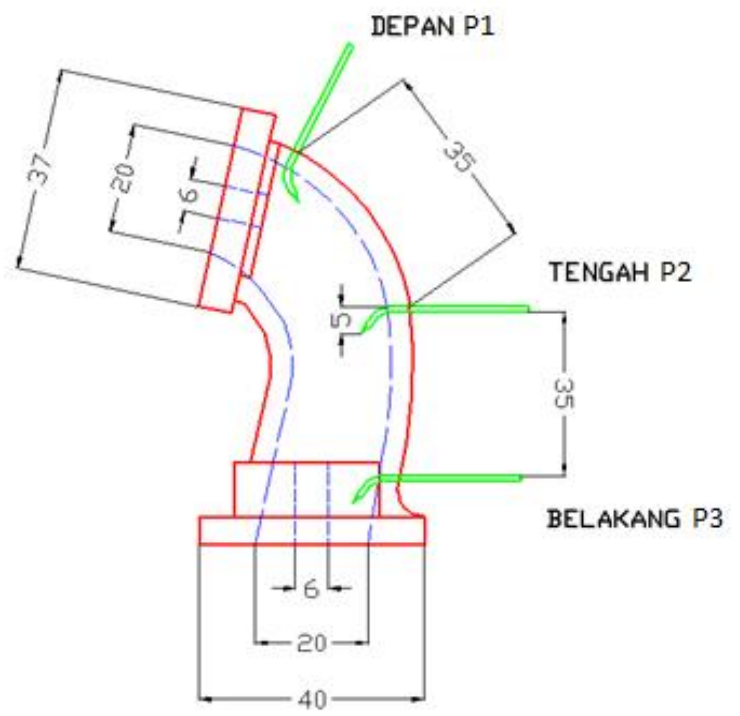

Gambar 3 Posisi penyemprotan ke dalam intake manifold

\section{HASIL DAN PEMBAHASAN}

Fuel Consumption (FC) merupakan ukuran pemakaian bahan bakar oleh suatu mesin, atau juga

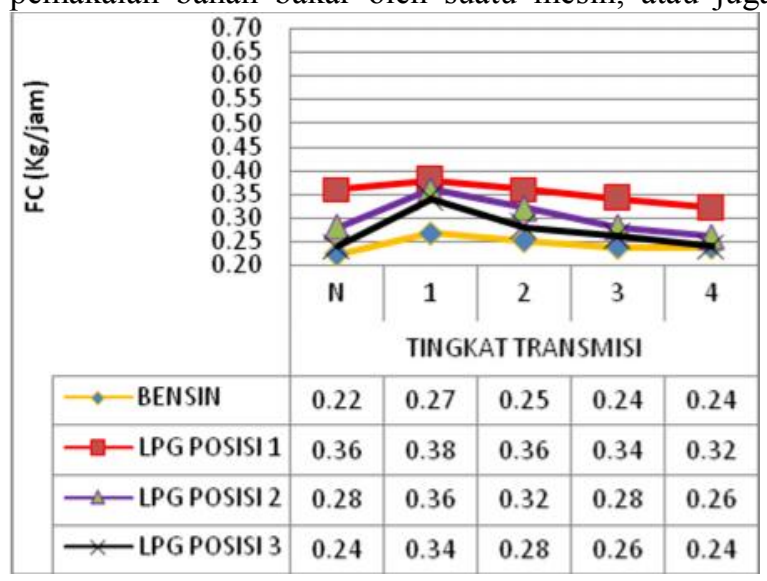

Grafik 1. Rerata nilai Fuel Consumption (FC) ujung yang mendekati karburator, bagian tengah, dan ujung yang mendekati katup bahan bakar.

dapat didefinisikan sebagai jumlah bahan bakar yang dikonsumsi oleh mesin selama waktu tertentu dalam satuan liter per jam.

Setelah dilakukan penelitian pengaruh penggunaan LPG terhadap Fuel Consumption (FC) didapat data sebagai berikut:

$$
\mathrm{FC}=\left(\frac{\text { volume bahan bakar }}{\text { waktu }}\right) \frac{\text { liter }}{\text { jam }}
$$

Sebagai contoh perhitungan diambil data pada tabel lampiran 2.1 untuk putaran $3000 \mathrm{rpm}$ pada transmisi netral dengan bakar bensin premium dimana volume bahan bakarnya adalah $\mathrm{V}=5(\mathrm{ml} / \mathrm{menit})$ :

$$
\begin{gathered}
F C=\frac{b}{t}\left(\frac{m l}{m n t}\right) \times p\left(\frac{k g}{m^{2}}\right) \times \frac{60}{1000000}\left(\frac{m m \cdot m^{3}}{j a m \cdot m l}\right) \\
\begin{array}{c}
5,0\left(\frac{m l}{m n t}\right) \times 743\left(\frac{\mathrm{kg}}{m^{3}}\right) \times \frac{60}{1000000}\left(\frac{m n t \cdot m^{8}}{j a m \cdot m l}\right) \\
=0,223(\mathrm{~kg} / \mathrm{jam})
\end{array}
\end{gathered}
$$

Selanjutnya untuk perhitungan $\mathrm{FC}$ rata-rata dapat dilihat pada tabel dibawah ini.

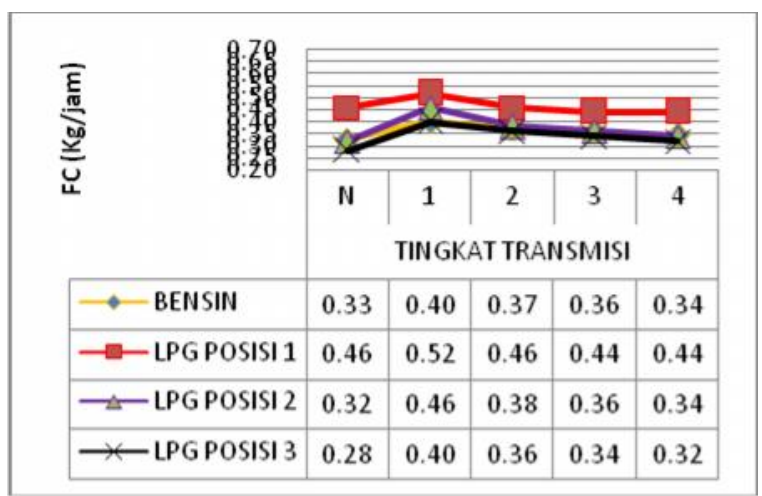

Grafik 2 FC pada berbagai tingkat transmisi pada putaran $3000 \mathrm{rpm}$ 


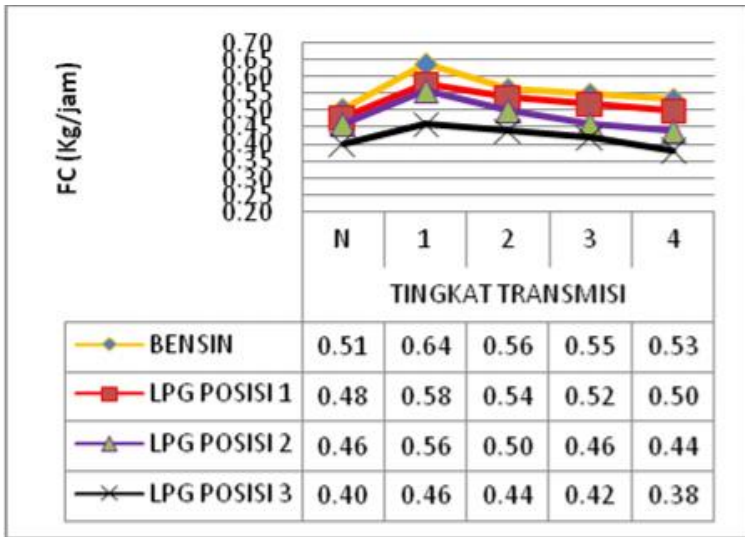

Grafik 3 FC pada berbagai tingkat transmisi pada putaran $4500 \mathrm{rpm}$

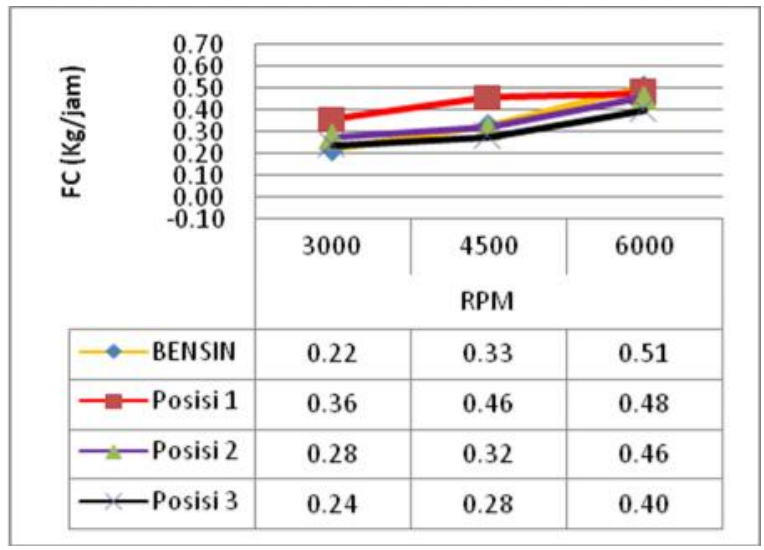

Grafik 4 FC pada berbagai tingkat transmisi pada putaran $6000 \mathrm{rpm}$

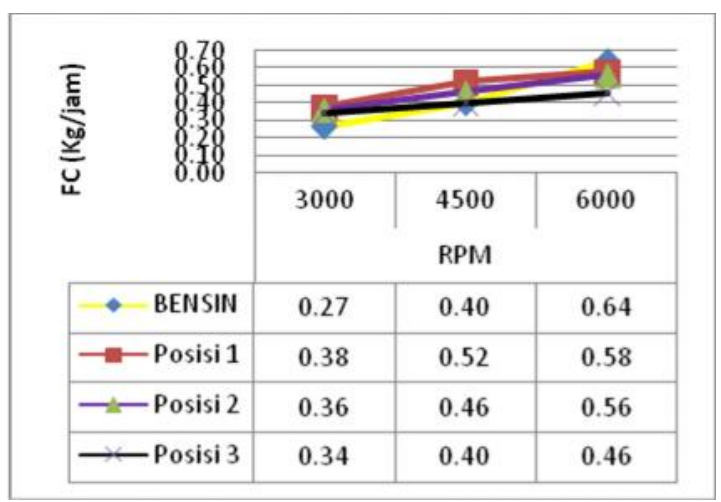

Grafik 5 RPM terhadap Fuel Consumption pada tingkat transmisi Netral

\section{KESIMPULAN}

Dari gambar di atas menunjukan bahwa konsumsi bahan bakar maksimum terjadi pada penggunaan bahan bakar bensin pada putaran 6000 rpm dengan tingkat transmisi ke-1 yaitu sebesar 0,64 $\mathrm{Kg} / \mathrm{jam}$, sedangkan konsumsi bahan bakar minimum terjadi pada penggunaan bahan bakar bensin pada

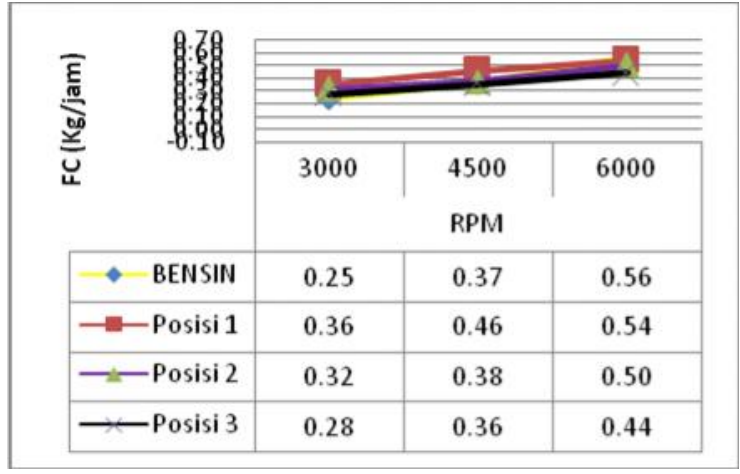

Grafik 6 RPM terhadap Fuel Consumption pada tingkat transmisi I

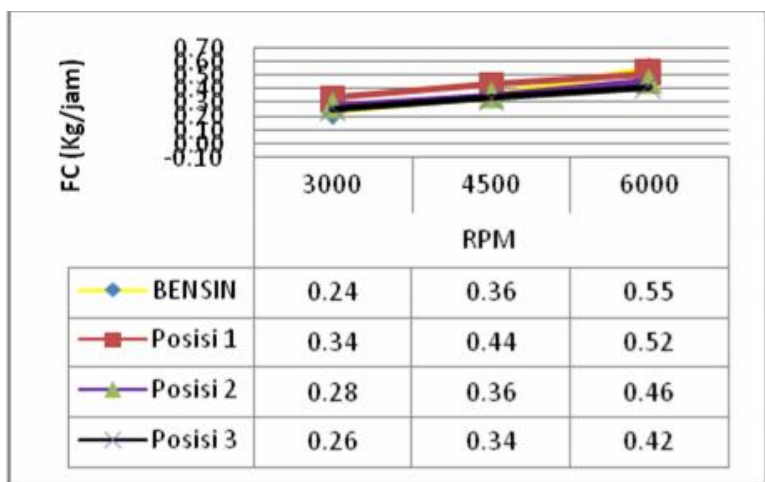

Grafik 7 RPM terhadap Fuel Consumption pada tingkat transmisi

II

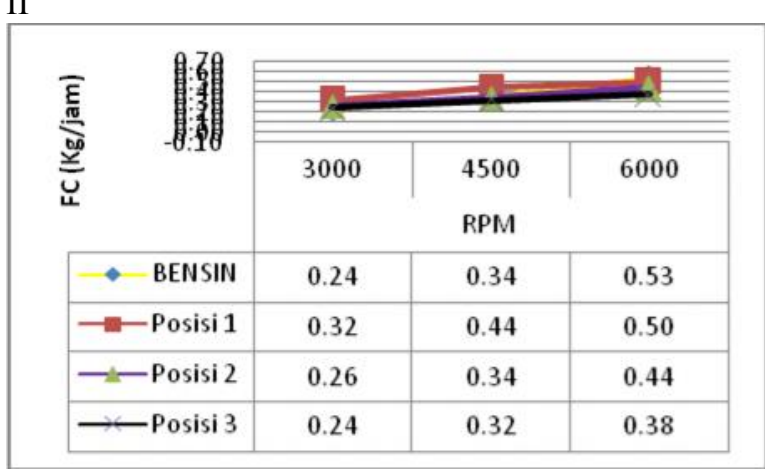

Grafik 8 RPM terhadap Fuel Consumption pada tingkat transmisi III

putaran $3000 \mathrm{rpm}$ dengan tingkat transmisi $\mathrm{N}$ yaitu sebesar $0,22 \mathrm{Kg} / \mathrm{jam}$.

Pada gambar di atas juga terlihat bahwa dengan meningkatnya putaran mesin diikuti pula dengan meningkatnya nilai Fuel Consumption (FC). Di mana pada putaran $3000 \mathrm{rpm}$ pemakaian bahan bakar lebih sedikit (irit) karena pada putaran mesin yang rendah membutuhkan suplai bahan bakar yang 
masuk ke dalam silinder tidak terlalu banyak, sedangkan pada putaran $6000 \mathrm{rpm}$ putaran mesin yang terjadi lebih cepat atau siklus pembakaran yang terjadi lebih banyak dibandingkan dengan putaran rendah per satuan waktu yang sama, sehingga suplai bahan bakar yang masuk ke dalam silinder juga lebih banyak.

Pada tingkat transmisi ke-1 terjadi penggunaan bahan bakar yang lebih banyak tinggi pada masing-masing penggunaan bahan bakar dan masing-masing putaran dikarenakan adanya pengaruh pembebanan (beban roda) yang diterima oleh mesin pada tingkat transmisi tersebut adalah yang paling besar sehingga untuk mengimbangi beban tersebut diperlukan suplai bahan bakar yang banyak, pada tingkat transmisi berikutnya pembebanan (beban roda) sudah berkurang sehingga suplai bahan bakar juga akan berkurang.

Apabila kita membandingkan nilai konsumsi bahan bakar LPG antara posisis 1, posisi 2 dan posisi 3, maka akan terlihat bahwa konsumsi bahan bahan bakar LPG pada posisi 3 lebih rendah dari pada posisi 1 dan posisi 2, bahkan pada putaran 4500 dan 6000 rpm nilai konsumsi bahan bakar pada posisi 3 ini lebih rendah dari pada nilai konsumsi bahan bakar pada penggunaan bahan bakar bensin. Penyemprotan bahan bakar gas yang dekat dengan ruang bakar akan mengakibatkan bahan bakar langsung menuju ke ruang bakar.

\section{DAFTAR PUSTAKA}

Abubakar Iskandar, 2003, Kerusakan Lingkungan yang Diakibatkan oleh Sumber Transportasi.

Anonim 1, 2002, Makara Teknologi, Vol.6, No. 3 Teknik Mesin Universitas Udayana

Anonim 2, 2006, Bahan Bakar \& Pembakaran, Hak cipta (C) United Nations Environment Programme (year) Pedoman Efisiensi Energi untuk Industri di Asia www.energyefficiencyasia.org.

Anonim 3, 1995, New step 1 Training Manual, Toyota Astra Motor.

Anonim 4, 2007, Kajian Dampak Penggunaan LPG Sebagai Bahan Bakar Alternatif Terhadap Mesin Kendaraan Bermotor Dan Lingkungan, Jakarta, Departemen Perhubungan Direktorat Jenderal Perhubungan Darat.

Anonim 5, 2001, Potrfolio Bahan Bakar Cair, Fakultas Teknik Universitas Indonesia, Depok.

Arismunandar, Wiranto, Prof, Dr, 1988, Motor Bakar Torak, Bandung; ITB Bandung,
Jadi, jika melihat data analisa statistik anova diatas maka jelas terlihat bahwa putaran mesin dan variasi posisi penyemprotan bahan bakar gas LPG pada setiap tingkat transmisi berpengaruh sangat nyata terhadap nilai konsumsi bahan bakar dengan taraf signifikan $1 \%$. Hal ini terbukti dimana nilai $\mathrm{F}$ hitung yang lebih besar dari F tabel. Namun bila melihat hubungan interaksi dari keduanya maka dapat dijelaskan bahwa tidak terjadi interaksi, hal ini terbukti dari nilai $\mathrm{F}$ hitung yang lebih kecil dari pada $\mathrm{F}$ tabel.

Setelah dilakukan penelitian, pengaruh posisi penyemprotan bahan bakar gas LPG pada intake manifold terhadap konsumsi bahan bakar dan emisi gas buang $\mathrm{CO}, \mathrm{CO}_{2}$, dan $\mathrm{HC}$ pada sepeda motor bensin empat langkah satu slinder (Honda Supra X), maka dapat diambil kesimpulan sebagai berikut :

1. Penyemprotan bahan bakar LPG pada posisi belakang (P3) didapatkan penurunan nilai konsumsi bahan bakar (FC) yang optimal dibandingkan pada posisi depan (P1) dan posisi tengah (P2) pada putaran 4500 dan $6000 \mathrm{rpm}$ terhadap penggunaan bahan bakar bensin.

2. Nilai konsumsi bahan bakar (FC) maksimum didapatkan pada tingkat transmisi 1 dibandingkan pada tingkat transmisi lainnya pada setiap variasi putaran mesin.

Arismunandar, Wiranto, Prof, Dr, 2004, Motor Diesel Putaran Tinggi, Jakarta; pradya Paramita.

Gill, Paul, W., James, H, Smith, Jr., Eugene, J, Ziurys, 1967, Fundamental of Internal Combustion Engine As Applied to Reciprocating, Gas Turbine, and Jet Propulsion Power Plants, Janpath New Delhi; Oxford \& IBH Publishing Co.

Heywood. John B, Prof, Dr, 1988, Internal Combustion Engine Fundamental, Singapore; Mc Graw-Hill book company Inc.

Jamaluddin, 2011, Pengaruh Penggunaan Bahan Bakar Gas LPG Terhadap Konsumsi Bahan Bakar Dan Emisi Gas Buang Pada Motor Bensin Empat Langkah Satu Silinder (Suzuki Shogun).

Keveney, Matt, 2006, Animated four stroke engine, http://www.keveney.com.

Kristanto. Philip, Gunawan. Jemy, 2001, Pengaturan Kondisi Idle dan Akselerasi pada Motor Berbahan Bakar Gas, Jurnal Teknik Mesin Volume 3 Nomor 2, Jurusan Teknik Mesin 
Fakultas Teknologi Industri Universitas Kristen Petra.

Kristanto, Philip, Willyanto, Wahyudi, Djoko, 2001, Pengaruh Perubahan Pemajuan Waktu Penyalaan Terhadap Motor Dual Fuel (Bensin-BAHAN BAKAR GAS), Jurnal Teknik Mesin Volume 3 Nomor 2, Teknik Mesin Fakultas Teknologi Industri Universitas Kristen Petra.

Tirtoatmodjo. Rahardjo, Wilianto, 1999, Peningkatan Performance Motor Bensin 4 Tak 3 Silinder yang Menggunakan Bahan Bakar Gas dengan Penambahan Blower dan Sistem Injeksi, Jurusan Teknik Mesin Fakultas Teknologi Industri, Universitas Kristen Petra. ( Download, 15 Juli 2009 )

Mara, I Made., Nuarsa. I Made, 2001, Diktat Motor Bakar, Mataram; Jurusan Teknik Mesin, Fakultas Teknik, Universitas Mataram.

Romadhona, 2010, Pengujian Unjuk Kerja Mesin Dengan Menggunakan Bahan Bakar Gas LPG Pada Motor Bensin Empat Langkah Satu Silinder (Suzuki Shogun).

Sitorus. Tulus Burhanuddin, ST, MT., 2002, Tinjauan pengembangan bahan bakar gas sebagai bahan bakar Alternatif, Fakultas Teknik Jurusan Teknik Mesin Universitas Sumatera Utara. 